\title{
Influence of Surgical Nurses' Information Behaviour on Surgical Patients' Pain Relief in Teaching Hospitals in Port Harcourt, Nigeria
}

\author{
Yemisi Temilola Babalola ${ }^{1} \quad$ Esther Esobuneta $^{2} \quad$ Rasidi Akinade Salawu ${ }^{2}$ \\ 1.Head of Department Information Resources Management, School of Management Sciences, Babcock \\ University Ilishan Remo, Ogun State, Nigeria \\ 2.Adult Health Department, School of Nursing Science, Babcock University Ilishan Remo, Ogun State
}

\begin{abstract}
Surgical patients need prompt and adequate pain relief after surgery. This required surgical nurses' need to acquire and use information to facilitate pain relief. The ability of surgical nurses' to seek and use pain management information would enhance patients' pain relief. Based on this assumption, the study investigated influence of nurses' information behaviour on surgical patients' pain relief in teaching hospitals in Port Harcourt. The study adopted survey design. A total sample of 786 drawn from the population of 3854 included 152 surgical nurses, 317 surgical patients, and 317 medication charts of the surgical patients using Krejcie and Morgan table. Multistage sampling technique was applied to select the participants. A validated questionnaire which was partly adapted, and medication charts audit checklist were used for data collection. Cronbach's alpha coefficients for the constructs ranged from 0.74 to 0.90 . Data were analyzed using descriptive and inferential statistics.Findings revealed that nurses' information behaviour components (Adj. $R 2=0.146,(F(2.143)=13.362$, $\mathrm{p}<0.05)$ had significant positive relative influence on surgical patients' pain relief. Nurses information behaviour $\left(R^{2}=0.144, \beta=0.380, p<0.05\right.$, significantly influence surgical patients' pain relief $\left.F(1,144)=24.253, \mathrm{p}<0.05\right)$. Findings revealed that surgical nurses' information behaviour was very good, average weighted mean $(\mathrm{M}=3.46)$. Further findings showed that surgical patients' level of pain relief was very high $(\mathrm{M}=1.75)$. The study concludes that nurses' information behaviour improved surgical patients' pain relief in teaching hospitals in Port Harcourt, Nigeria. The study recommends that surgical nurses should improve on their information seeking and use behaviour to maintain pain relief among surgical patients.
\end{abstract}

Keywords: Nurses' information seeking, Nurses' information use, Pain relief, Surgical patients' pain relief, Teaching Hospitals

DOI: $10.7176 / \mathrm{IKM} / 11-3-03$

Publication date: April $30^{\text {th }} 2021$

\section{Introduction}

Pain is a common discomfort that is experienced by many worldwide. Pain is common with surgical patients as a result of the presence of surgical incision. Pain could also be psychological without any physical injury. People who experienced pain respond to it in different ways. Pain by virtue of its universality is not a respecter of persons and as such affects everyone regardless of the status, age, gender and other personal characteristics. Surgical patients' pain must be eliminated so that they can experience pain relief. Surgical patients require their pain to be treated in order to keep the patient comfortable and capable of participating in activities of daily living. Evidences reveal that untreated surgical pain could become persistent and severe, transforming to chronic pain which challenges the wellbeing of patients (Rababa, 2018; Stodart \& McCallum, 2014). Successful administration of analgesics is subject to the nurses being able to identify, and access all necessary information relating to the patient's pain treatment in order to give the analgesics appropriately to the patient. Acquiring relevant information relating to analgesics treatment is important for nurses to effectively administer pain treatment for adequate surgical patients' pain relief. In view of the importance of nurses' information behaviour in this regard, the understanding of information relating to pain management is essential.

Generally, information regarding pain management includes facts about the pain itself, the person having the pain, strategies developed to alleviate the pain, circumstances around the pain treatment and factors that can affect the pain relief, as well as pain management standards of care. These information relating to surgical patients' pain management include patients' self-report of pain which will include type of pain, location of the pain, pain intensity, factors affecting present pain (palliative and aggravating) and level of comfort expected by the patient. Fishman, Young. Arwood, Chou, Herr, Murinson et al. (2013) argue that information relating to pain management could be gained from nursing training, clinical practice experience, patient assessment, clinical practice guidelines, online databases, and continued education. This information must be applied in current patient pain management care to achieve pain relief.

Nurses need to acquire all necessary information relating to surgical patients' pain management and use such to administer analgesics that would relieve patients' pain. March, Vaikosen, and Akporaghene (2020) note 
that nurses require to seek information in relation to their responsibility as health professionals and such responsibilities include administration of analgesics to post-operative patients. Nurses also seek information from patients in the form of pain assessment and evaluation of treatment effectiveness. In nursing practice, it is important for nurses to seek information they need to meet professional practice standard of care such as clinical practice guidelines or protocol to achieve effective patient care (Hinkle \& Cheever, 2018). Consequently, managing acute surgical pain requires the nurse to apply the knowledge of pain management and information science by means of demonstrating information behaviour. Therefore, access to and the use of information relating to pain management by nurses caring for patients after surgical operation is vital and cannot be overemphasized.

Nurses caring for surgical patients during the post-operative period require information that is relevant to acute pain management and its associated problems. Access to and use of such information is expected to support nurses in the delivery of precise pain management care that is effective in relieving surgical patients' pain. Nurses' information behaviour include the manner in which nurses seek and use information relating to pain management forms their information behaviour with respect to pain management. Wilson (2016) identified information behaviour (IB) as the entirety of human behaviour in relation to sources and channels of information; including information seeking and its usage. This author also acknowledged that information behaviour consists of three core components which are information need, information seeking, and information use. However, this study considered surgical nurses' information seeking behaviour and use.

Surgical nurses, who are responsible for managing surgical patients' post-operative pain, seek relevant information on pain management and use it to facilitate effective pain relief. Nurses need information on how to maintain their competency in pain management care. Nurses may also desire information to enable them to cope with challenges encountered in the care of the post-operative patient from different surgical contexts. Nurses also need information on the advantages and disadvantages of one pain management approach from the other. Meeting these pain management information needs requires nurses to seek for information in order to locate and use them.

Information seeking denotes the individual's quest for information to bridge knowledge gaps. Kehinde, Obi, Akinde and Anyim (2016) submit that information seeking refers to an individualized action that involves personally looking for and obtaining information for accomplishing tasks, updating knowledge and skills for personal and professional use. This notion of information seeking could be applied by nurses who are providing pain management care to post-surgical patients. Nurses may perhaps seek information when they identify that they have a lack of significant knowledge about patients' surgery, the type of pain that may occur, and the strategy for the treatment of such pain. Information seeking refers to conscious efforts to acquire information that will meet the needs of individuals that lack significant familiarity to the specialty. March et al. (2020) observed that information seeking behaviour involves identifying the need for information, activities for searching, assembling, analyzing and using information in a worthwhile manner. Vigharajah, Hassan, AbdAziz, and Lee (2016) discuss information seeking as an interactive process that leads to locating and acquiring anticipated information. This implies that information seeking entails actions and strategies that surgical nurses take to locate relevant information to accomplish tasks of managing surgical patients' pain.

Opeke (2017) identified information use as the action people carry out with the acquired information which involves thinking and doing. Information use in is viewed as a precursor to effective decision making. The application of pain management information in clinical practice could be demonstrated in the elimination of uncertainty (March et al., 2020) regarding pain management. Evidence shows that when information about pain management is applied to current pain care delivery in surgical care, effective pain relief can be achieved (Sampson, 2013).

\subsection{Statement of the problem}

Surgical patients expect to achieve acceptable pain relief from their post-operative pain management after their surgery. However, some patients and clinicians have perceived that surgical patients in teaching hospitals in Port Harcourt do not achieve satisfactory pain relief during the post-operative period. Surgical patients' displeasure with their pain relief is apparent in the way they complain of pain during activities of daily living and wound dressing. In situations when patients' pain is not effectively relieved, the pain could progress to severe and chronic pain which disturbs patients' participation in activities of daily living. Thus, they will feel disgruntled with the pain management and the care they receive from the teaching hospital. Literature indicates that in recent time, pain management approaches have improved nevertheless these have not turned to pain relief for surgical patients (Chou et al., 2016; Subramanian et al., 2017).

In post-operative pain management, surgical nurses' ability to seek and use information pertaining to pain management has potential to influence surgical patients' pain relief. Achieving adequate pain relief requires nurses to accurately administer scheduled analgesics to patients and this requires appropriate information behaviour but this is currently problematic world-wide. This implies that nurses' would need to demonstrate 
information behaviour which involves seeking for information and using such information to administer prescribed scheduled analgesics to achieve pain relief. But it is not certain that surgical nurses are indicating appropriate information behaviour in the administration of scheduled analgesics to results in surgical patients' pain relief in teaching hospitals in Port Harcourt. Consequently the treatment given may not achieve sustained pain relief for surgical patients. Therefore, this study investigated the influence of nurses' information behaviour on surgical patients' pain relief in teaching hospitals in Port Harcourt, Nigeria.

The study answered two questions and tested two null hypotheses

\subsection{Research Questions}

The study answered the following questions:

1. What is the surgical patients' level of pain relief in teaching hospitals in Port Harcourt, Nigeria?

2. What is the surgical nurses' information behaviour with respect to pain management in teaching hospitals in Port Harcourt, Nigeria?

\subsection{Research Hypotheses}

The following null hypotheses were tested at 0.05 , level of significance.

Ho1: Nurses' information behaviour has no significant influence on surgical patients' pain relief in teaching hospitals in Port Harcourt, Nigeria

Ho2: Nurses' information seeking and information use have no significant relative influence on surgical patients' pain relief in teaching hospitals in Port Harcourt, Nigeria

\subsection{Literature review}

Surgical patients require adequate pain relief to recover from surgery. Patients' recovery from their treatment enhances their appreciation and appraisal of the care received and also encourages them to use the health facility in the future. It is also important for surgical patients to achieve adequate pain relief so that they can maintain functional status as well as prevent post-operative complications. Relieved surgical pain would also enhance surgical patients' healing and reduce their hospital stay. This could reduce their hospital expenses and enable them to perceive the hospital positively.

Schroeder, Hoffman, Fioravanti, Medley, Zullo and Tuite (2016) studied nurses' pain assessment and found that nurses' knowledge improved patients' satisfaction with pain relief. In another study by Mubita, Richardson and Briggs (2019) on patients' satisfaction with pain relief following abdominal surgery, they found that satisfaction with pain relief was dependent on proper communication which is part of information behaviour. In a study conducted in Ireland by O'Leary, and Ni Mhaolrunaiah (2011) on where nurse seek information found that nurses accessed their nursing colleagues and guidelines as prepackaged information instead of original research. They also reported that nurses' information behaviour for routine decision was reliant on experience. Another study in Greece by Argyri, Kostagiolas and Diomidous (2014) which used survey design revealed that nurses' information seeking behaviour had effect on nursing care. The result implied that nurses' information behaviour could influence post-operative pain management by nurses.

Other studies in Nigeria by Onianwa, Alonge, Otegbayo, Ike, Chukura, Akanbi et al. (2017) and Nwagwu and Oshiname (2009) found that nurses and other health care professionals can obtain information related to pain management through the process of patient assessment. This is necessary because it would guide the nurse in appropriate decision about administration of analgesics. In the study by Baro and Ebhomeya (2013) that surveyed two hospitals in Bayelsa State on information needs and seeking behaviour of nurses, findings showed among other needs nurses sought information for medication administration.

\subsection{Methodology}

3.1 Research Design: This study used a survey method to examine the influence of nurses' information behaviour on surgical patients' pain relief in teaching hospitals in Port Harcourt, Nigeria.

3.2 Population: The total population of this study was 3854 comprising of 250 surgical nurses, 1802 surgical patients, and 1802 medication charts of the surgical patients. The nurses' included 174 nurses from University of Port Harcourt Teaching Hospital (UPTH) and 76 nurses from the Rivers State University Teaching Hospital (RSUTH) both in Port Harcourt. The surgical patients' population comprised of 959 adult surgical patients from UPTH and 843 from RSUTH and corresponding numbers of medication charts as the surgical patients from each teaching hospital. Inclusion criteria: Patients who had surgery and were admitted for at least 24 hours for postoperative care and had pain in the past 24 hours were included. Nurses were included if they had a minimum of six months surgical experience and were not on leave during data collection period. Patients and nurses were included if they voluntarily accept to participate in the study. 
3.3 Sample size and Sampling technique: A total sample of 786 comprising of 152 surgical nurses, 317 surgical patients and 317 medication charts was drawn from the population using Krejcie and Morgan table (1970). A two-stage sampling technique was used in selecting the teaching hospitals and research participants. At the first stage, purposive sampling method was used to select the two university teaching hospitals in Port Harcourt. Convenience method was used because all the patients were not admitted to the hospital at the same time but according to the date of their surgery.

\subsection{Instrumentation:}

The instrument for data collection was questionnaire for nurses, patients and medication chart audit checklist. The patient questionnaire was labelled patients' pain outcome questionnaire and was modified from the Revised American Pain Society Patient Outcome Questionnaire (APS-POQ-R) (Subramanian et al., 2017). Surgical patients' pain relief was measured using pain score on numeric rating scale (NRS). The scale rates from ' 0 ' to ' 10 ' with ' 0 ' representing no pain while ' 10 ' represents the worst pain that can be experienced. However, this scale was recoded to a 5 point scale to facilitate analysis and interpretation. The recoded 5 point scale was $0=$ no pain, 1-3 = mild pain, 4-6 = moderate pain, 7- $8=$ not very severe pain, and 9-10 = very severe or excruciating pain.

The nurses' questionnaire was used to collect data on information seeking and information use behaviour by surgical nurses who provide care for post-operative patients and managed their pain in the two teaching hospitals in Port Harcourt. The nurses' instrument was developed for this study and named nurses' information seeking and use questionnaire (NISUQ). This questionnaire consisted of two sections, A, and B, which are described below:

Section A consists of socio-demographic profiles of the respondents while section B collected data relating to nurses' information behaviour (information seeking and use). Responses on section B were measured using 4 point Likert-scale type questions, Strongly Agree $(\mathrm{SA})=4$, Agree $(A)=3$, Disagree $(\mathrm{D})=2$, Strongly Disagree $(\mathrm{SD})=1$.

\subsection{Reliability and Validity of Instrument}

Face and content validity was performed by information science experts as well as expert nurses in Information Resources Management and School of nursing Sciences and Clinical Nurses in the Babcock University Teaching Hospital. The instrument was pre-tested on similar population that was not part of this study. The Cronbach's alpha coefficient for all sections of questionnaire ranged from 0.74 to 0.90 . Construct validity revealed AVE 0.621 to 0.810 ; KMO 0.516 to 0.821 and Bartlett's test of Sphericity 0.000 in all constructs.

3.6 Method of Data Collection: The purpose of the study was explained to the participants and their concerns were clarified. Informed consent was gained before data collection. Data collection involved administration of 152 copies of the nurses' questionnaire and 317 copies of patients' questionnaire were administered to the participants in both teaching hospitals with the help of nurse research assistants who were trained for the purpose.

3.7 Method of Data Analysis: Completed copies of the questionnaire were processed and validated copies were entered into the computer using software Statistical Package for Social Sciences (SPSS) Version 23. Analysis was performed by descriptive and inferential statistics.

3.8 Ethical Consideration: Ethical approvals were sought and obtained from Babcock University Human Research Ethics Committee (BUHREC) and the Ethical Committees of the two University Teaching Hospitals in Port Harcourt where the study took place. Ethical principles were followed during the process of the study. No conflict of interest existed in this study.

\subsection{Results}

The copies of nurses' questionnaire administered were 152 but 146 copies were retrieved and validated for analysis. Likewise, 317 copies of questionnaire was administered to patients and 317 medication charts audits were completed and 262 copies of questionnaire and medication checklist were retrieved and validated for analysis. 
Table 1: Surgical Patients' Socio-demographic Characteristics

\begin{tabular}{|c|c|c|c|}
\hline Variable & Categories & Frequency (n) & Percentage (\%) \\
\hline \multirow[t]{7}{*}{ Age } & $18-30$ years & 75 & 28.6 \\
\hline & $31-40$ years & 80 & 30.5 \\
\hline & $41-50$ years & 66 & 25.2 \\
\hline & $51-60$ years & 19 & 7.3 \\
\hline & $61-65$ years & 11 & 4.2 \\
\hline & Above 65 years & 11 & 4.2 \\
\hline & Total & 262 & 100 \\
\hline \multirow[t]{3}{*}{ Gender } & Male & 98 & 37.4 \\
\hline & Female & 164 & 62.6 \\
\hline & Total & 262 & 100 \\
\hline \multirow[t]{3}{*}{ Religion } & Christianity & 247 & 92.3 \\
\hline & Islam & 15 & 5.7 \\
\hline & Total & 262 & 100 \\
\hline \multirow[t]{8}{*}{ Surgical specialty } & General surgery & 84 & 32.1 \\
\hline & Orthorpaedic & 76 & 29.0 \\
\hline & Obstetrics \& Gynecology & 69 & 26.3 \\
\hline & ENT & 03 & 1.1 \\
\hline & Ophthalmology & 07 & 2.7 \\
\hline & Plastics and Burns & 11 & 4.2 \\
\hline & Surgical OPD & 12 & 4.6 \\
\hline & Total & 262 & 100 \\
\hline \multirow{7}{*}{$\begin{array}{l}\text { Number of days since } \\
\text { surgery in the specialty }\end{array}$} & 1-3 days & 84 & 32.1 \\
\hline & 4-6 days & 92 & 35.1 \\
\hline & $7-10$ days & 42 & 16.0 \\
\hline & $11-15$ days & 18 & 6.9 \\
\hline & $16-20$ days & 13 & 5.0 \\
\hline & 20 days and above & 13 & 5.0 \\
\hline & Total & 262 & 100 \\
\hline \multirow[t]{6}{*}{ Highest education attained } & Primary & 08 & 3.1 \\
\hline & Secondary & 46 & 17.6 \\
\hline & Post-secondary & 59 & 22.5 \\
\hline & Tertiary & 145 & 55.3 \\
\hline & Others & 04 & 1.5 \\
\hline & Total & 262 & 100 \\
\hline \multirow[t]{5}{*}{ Employment status } & Unemployed & 35 & 13.4 \\
\hline & Civil servant & 122 & 46.5 \\
\hline & Self-employed & 84 & 32.1 \\
\hline & Others & 21 & 8.0 \\
\hline & Total & 262 & 100 \\
\hline
\end{tabular}

Table 1: Majority 164(62.6\%) respondents were females while 98 (37.4\%) were males. This implies that more females visited the teaching hospitals in Port Harcourt. This may be due to surgeries related to obstetrics and gynaecology which are absolutely associated with women. Results further indicated that 84 (32.1\%), 76 $(29.0 \%)$ and $69(26.3 \%)$ of surgical patients respectively visited general surgery, orthorpaedic and obstetrics and gynecology departments of teaching hospitals in Port Harcourt. 
Table 2: Surgical Nurses' Socio-demographic Characteristics

\begin{tabular}{|c|c|c|c|}
\hline Variable & Categories & Frequency (n) & Percentage (\%) \\
\hline \multirow[t]{6}{*}{ Age } & 21-30 years & 28 & 19.2 \\
\hline & $31-40$ years & 47 & 32.2 \\
\hline & $41-50$ years & 39 & 26.7 \\
\hline & 50- 50 years & 29 & 19.8 \\
\hline & $61-65$ years & 03 & 2.1 \\
\hline & Total & 146 & 100 \\
\hline \multirow[t]{3}{*}{ Gender } & Male & 14 & 9.6 \\
\hline & Female & 132 & 90.4 \\
\hline & Total & 146 & 100 \\
\hline \multirow[t]{3}{*}{ Religion } & Christianity & 142 & 97.3 \\
\hline & Islam & 04 & 2.7 \\
\hline & Total & 146 & 100 \\
\hline \multirow[t]{8}{*}{ Surgical specialty } & General surgery & 56 & 38.4 \\
\hline & Orthorpaedic & 21 & 14.4 \\
\hline & Obstetrics \& Gynecology & 43 & 29.5 \\
\hline & ENT & 03 & 2.1 \\
\hline & Ophthalmology & 02 & 1.4 \\
\hline & Plastics and Burns & 14 & 9.6 \\
\hline & Surgical OPD & 07 & 4.8 \\
\hline & Total & 146 & 100 \\
\hline \multirow[t]{7}{*}{ Years in the specialty } & $1-2$ years & 55 & 37.7 \\
\hline & $3-5$ years & 34 & 23.3 \\
\hline & $6-10$ years & 25 & 17.1 \\
\hline & $11-15$ years & 09 & 6.2 \\
\hline & $16-20$ years & 09 & 6.2 \\
\hline & 20 years and above & 14 & 9.6 \\
\hline & Total & 146 & 100 \\
\hline \multirow[t]{6}{*}{ Years in service } & $1-4$ years & 37 & 25.3 \\
\hline & $5-10$ years & 32 & 21.9 \\
\hline & $11-15$ years & 32 & 21.9 \\
\hline & $16-20$ years & 17 & 11.6 \\
\hline & 21 years and above & 28 & 19.2 \\
\hline & Total & 146 & 100 \\
\hline \multirow[t]{5}{*}{ Professional qualification } & Nurses with one qualification & 39 & 26.7 \\
\hline & Nurses with two qualifications & 59 & 40.4 \\
\hline & Nurses with three qualifications & 44 & 30.1 \\
\hline & Nurses with four qualifications & 4 & 2.7 \\
\hline & Total & 146 & 100 \\
\hline
\end{tabular}

Table 2 Findings show that $132(90.4 \%)$ of the nurses were females while $14(9.6 \%)$ were males.

Findings further showed that 101(69.1\%) of surgical nurses in teaching hospitals in Port Harcourt had one to 15 years in the service. Furthermore, 107 (73.2\%) of surgical nurses in the teaching hospitals had at least two professional qualifications in the field of nursing. 
Research Question One: What is the surgical patients' level of pain relief in teaching hospitals in Port Harcourt?

Table 3: Surgical Patients' Level of Pain Relief in Teaching Hospitals in Port Harcourt

\begin{tabular}{|c|c|c|c|c|c|c|c|}
\hline Pain Outcome & $\begin{array}{c}\text { No } \\
\text { Pain(1) }\end{array}$ & $\begin{array}{c}\text { Mild } \\
\text { Pain } \\
(2)\end{array}$ & $\begin{array}{l}\text { Moderate } \\
\text { Pain } \\
\text { (3) }\end{array}$ & $\begin{array}{l}\text { Not very } \\
\text { Severe } \\
\text { Pain } \\
\text { (4) }\end{array}$ & $\begin{array}{l}\text { Severe } \\
\text { Pain } \\
\text { (5) }\end{array}$ & Mean & $\begin{array}{l}\text { Std. } \\
\text { Dev. }\end{array}$ \\
\hline $\begin{array}{l}\text { Severity of pain (decrease } \\
\text { in pain) }\end{array}$ & & & & & & 2.58 & 0.61 \\
\hline $\begin{array}{l}\text { On this scale, please tick }[\sqrt{ }] \\
\text { the worst pain you had in the } \\
\text { past } 24 \text { hours }\end{array}$ & $02(0.8)$ & $38(14.5)$ & $101(38.5)$ & $84(32.1)$ & $37(14.1)$ & 3.44 & 0.93 \\
\hline $\begin{array}{l}\text { In the past } 24 \text { hours what is } \\
\text { the percentage of pain relief } \\
\text { you achieved from your } \\
\text { regular analgesics? }\end{array}$ & 0 & $10(3.8)$ & $123(46.9)$ & $88(33.6)$ & $41(15.6)$ & 2.61 & 0.79 \\
\hline $\begin{array}{l}\text { Please tick }[\sqrt{ }] \text { the number } \\
\text { that shows the pain you feel } \\
\text { while trying to move in bed }\end{array}$ & $20(7.6)$ & $127(48.6)$ & $87(33.2)$ & $25(9.5)$ & $03(1.1)$ & 2.48 & 0.82 \\
\hline $\begin{array}{l}\text { On this scale, Please tick }[\sqrt{ }] \\
\text { the least pain you had in the } \\
\text { past } 24 \text { hours }\end{array}$ & $12(4.6)$ & $163(62.2)$ & $80(30.5)$ & $07(2.7)$ & 0 & 2.31 & 0.60 \\
\hline $\begin{array}{l}\text { Please tick }[\sqrt{ }] \text { the number } \\
\text { that shows the pain you feel } \\
\text { while lying in bed resting } \\
\text { without moving }\end{array}$ & $73(27.9)$ & $122(46.6)$ & $45(17.1)$ & $22(8.4)$ & 0 & 2.06 & 0.89 \\
\hline $\begin{array}{l}\text { How often were you in severe } \\
\text { pain in the past } 24 \text { hours? }\end{array}$ & $83(31.7)$ & $106(40.5)$ & $61(23.3)$ & $09(3.4)$ & 03(1.1) & 2.02 & 0.89 \\
\hline $\begin{array}{l}\text { Activities Associated with } \\
\text { Pain: } \\
\text { Please indicate how pain } \\
\text { prevents you from doing any } \\
\text { of the following activities in } \\
\text { the past } 24 \text { hours: }\end{array}$ & & & & & & 1.85 & 0.85 \\
\hline $\begin{array}{l}\text { Doing activities out of bed } \\
\text { such as walking, sitting in a } \\
\text { chair, changing clothes }\end{array}$ & $54(20.6)$ & $115(43.9)$ & $67(25.6)$ & $21(8.0)$ & $05(1.9)$ & 2.27 & 0.94 \\
\hline $\begin{array}{l}\text { Doing activities in bed such } \\
\text { as turning, sitting up, } \\
\text { repositioning }\end{array}$ & $91(34.8)$ & $99(37.8)$ & $52(19.8)$ & $15(5.7)$ & $05(1.9)$ & 2.02 & 0.98 \\
\hline Falling asleep & $130(49.6)$ & $78(29.8)$ & $36(13.7)$ & $13(5.0)$ & $05(1.9)$ & 1.80 & 0.98 \\
\hline Remaining asleep & $154(58.8)$ & $63(24.0)$ & $30(11.4)$ & $13(5.0)$ & $02(0.8)$ & 1.65 & 0.92 \\
\hline $\begin{array}{l}\text { Emotions Associated with } \\
\text { Pain: } \\
\text { How much did you feel any } \\
\text { of these emotions because of } \\
\text { your pain: }\end{array}$ & & & & & & 1.32 & 0.68 \\
\hline Anxious & $206(78.6)$ & $34(13.0)$ & $15(5.7)$ & $05(1.9)$ & $02(0.8)$ & 1.33 & 0.74 \\
\hline Helpless & $217(82.8)$ & $22(8.5)$ & $15(5.7)$ & $05(1.9)$ & $02(1.1)$ & 1.30 & 0.76 \\
\hline Frightened & $219(83.6)$ & $20(7.6)$ & $14(5.4)$ & $06(2.3)$ & 03(1.1) & 1.30 & 0.77 \\
\hline Depressed & $225(85.9)$ & $17(6.6)$ & $14(5.3)$ & $03(1.1)$ & $03(1.1)$ & 1.25 & 0.72 \\
\hline
\end{tabular}




\begin{tabular}{|c|c|c|c|c|c|c|c|c|}
\hline Pain Outcome & $\begin{array}{c}\text { No } \\
\text { Pain(1) }\end{array}$ & & $\begin{array}{l}\text { Mild } \\
\text { Pain } \\
\text { (2) }\end{array}$ & $\begin{array}{c}\text { Moderate } \\
\text { Pain } \\
\text { (3) }\end{array}$ & $\begin{array}{l}\text { Not very } \\
\text { Severe } \\
\text { Pain } \\
\text { (4) }\end{array}$ & $\begin{array}{c}\text { Severe } \\
\text { Pain } \\
\text { (5) }\end{array}$ & Mean & $\begin{array}{l}\text { Std. } \\
\text { Dev. }\end{array}$ \\
\hline $\begin{array}{l}\text { Side Effects of Analgesia: } \\
\text { Please indicate the frequency } \\
\text { you have experienced any of } \\
\text { the following side effects } \\
\text { from your analgesics in the } \\
\text { past } 24 \text { hours: }\end{array}$ & & & & & & & 1.23 & 0.46 \\
\hline Dizziness & $200(76.3)$ & & $7(14.1)$ & $17(6.5)$ & $02(0.8)$ & $06(2.3)$ & 1.39 & 0.83 \\
\hline Drowsiness & $201(76.7)$ & & $5(13.7)$ & $21(8.0)$ & $02(0.8)$ & $02(0.8)$ & 1.35 & 0.73 \\
\hline Nausea & 199(76.0) & & $(19.1)$ & $10(3.8)$ & 0 & 03(1.1) & 1.31 & 0.66 \\
\hline Itching & $234(89.6)$ & & $7(7.3)$ & $07(2.7)$ & $01(0.4)$ & 0 & 1.14 & 0.44 \\
\hline Average Weighted Mean & & & & & & & 1.75 & 0.42 \\
\hline \multicolumn{9}{|c|}{$\begin{array}{l}\text { Pain outcome scale was recoded as: } 0=0 \text { (no pain), } 1-3=1 \text { (mild pain), } 4-6=3 \text { (moderate pain), } 7-8=4 \text { (not very } \\
\text { severe pain), } 9-10=5 \text { (severe pain) based on Subramanian et al., }(2017) \text { suggestion. }\end{array}$} \\
\hline \multicolumn{9}{|c|}{$\begin{array}{l}\text { Decision Rule: If mean is } 4.21 \text { to } 5.0=\text { very low pain relief; } 3.41 \text { to } 4.20=\text { low pain relief; } \\
2.61 \text { to } 3.40=\text { moderate pain relief; } 1.81 \text { to } 2.60=\text { high pain relief; } 1.0 \text { to } 1.80=\text { Very high pain relief. Criterion } \\
\text { Mean }=3.0 \\
\text { Table } 3 \text { showed that the level of surgical patients' pain relief was very high. The items used to measure pain } \\
\text { relief were severity of pain, activities associated with pain, emotions associated with pain and side effects of } \\
\text { analgesics. Among the dimensions of pain outcome, severity of pain had the highest mean score }(\mathrm{M}=2.58) \text {, } \\
\text { followed by activities associated with pain }(\mathrm{M}=1.85) \text {, emotions associated with pain }(\mathrm{M}=1.32) \text {, while side } \\
\text { effects of analgesics had the lowest mean score }(\mathrm{M}=1.23) \text {. The Average Weighted Mean Score of } 1.75 \text { falls } \\
\text { below the criterion mean of } 3.0 \text { which indicated that the surgical patients' level of pain relief was very high. } \\
\text { Research Question Two: What is the surgical nurses' information behaviour regarding pain management } \\
\text { in teaching hospitals in Port Harcourt? } \\
\text { Table } 4 \text { : Surgical Nurses' Information Behaviour with respect to Pain Management in } \\
\text { Teaching Hospitals in Port Harcourt }\end{array}$} \\
\hline & & & SA (4) & A (3) & $\mathbf{D}(2)$ & SD (1) & Mean & $\begin{array}{l}\text { Std. } \\
\text { Dev. }\end{array}$ \\
\hline $\begin{array}{l}\text { Information Seeking Behaviou } \\
\text { I seek information in the followi }\end{array}$ & ur: & & & & & & 3.47 & 0.51 \\
\hline $\begin{array}{l}\text { Reading patient's post-operati } \\
\text { regarding pain management }\end{array}$ & ve instructi & & $\begin{array}{l}97 \\
(66.4)\end{array}$ & $43(29.5)$ & $02(1.4)$ & $04(2.7)$ & 3.60 & 0.66 \\
\hline $\begin{array}{l}\text { Reading patient's medication o } \\
\text { correct drug and dosage }\end{array}$ & rder chart $\mathrm{f}$ & & $80(54.8)$ & $54(37.0)$ & $12(8.2)$ & 0 & 3.47 & 0.65 \\
\hline $\begin{array}{l}\text { Conducting patient's pain asse } \\
\text { pain measurement scale }\end{array}$ & essment usi & & $85(58.2)$ & $46(31.5)$ & $09(6.2)$ & $06(4.1)$ & 3.44 & 0.79 \\
\hline $\begin{array}{l}\text { Reading nurses' report on patien } \\
\text { with pain relief }\end{array}$ & tt's experien & & $65(44.5)$ & $68(46.6)$ & $11(7.5)$ & $02(1.4)$ & 3.34 & 0.68 \\
\hline $\begin{array}{l}\text { Reading evaluation data on side } \\
\text { administered analgesics }\end{array}$ & effects of $t$ & & $39(26.7)$ & $92(63.0)$ & $92(63.0)$ & $03(2.1)$ & 3.14 & 0.64 \\
\hline $\begin{array}{l}\text { Reading evaluation data on ef } \\
\text { analgesics administered }\end{array}$ & fectiveness & & $40(27.4)$ & $85(58.2)$ & $20(13.7)$ & $01(0.7)$ & 3.12 & 0.65 \\
\hline $\begin{array}{l}\text { Reading pain management } \\
\text { protocols / policy document }\end{array}$ & guidelines & & $35(24.0)$ & $81(55.5)$ & $25(17.1)$ & $05(3.4)$ & 3.00 & 0.74 \\
\hline Reading online information on a & nalgesics & & $36(24.7)$ & $58(39.6)$ & $43(29.5)$ & $09(6.2)$ & 2.83 & 0.87 \\
\hline $\begin{array}{l}\text { Conducting databases search fo } \\
\text { acute pain management updates }\end{array}$ & research & & $24(16.4)$ & $75(51.4)$ & $32(21.9)$ & $15(10.3)$ & 2.74 & 0.86 \\
\hline $\begin{array}{l}\text { Consulting medical staff, pharm } \\
\text { colleagues }\end{array}$ & acist, or nur & & $23(15.8)$ & $72(49.3)$ & $41(28.1)$ & $10(6.8)$ & 2.74 & 0.81 \\
\hline
\end{tabular}




\begin{tabular}{|c|c|c|c|c|c|c|}
\hline & SA (4) & A (3) & $\mathbf{D}(2)$ & SD (1) & Mean & $\begin{array}{l}\text { Std. } \\
\text { Dev. }\end{array}$ \\
\hline $\begin{array}{l}\text { Listening to patient's family on concerns } \\
\text { about patient's pain }\end{array}$ & $28(19.2)$ & $62(42.4)$ & $41(28.1)$ & $15(10.3)$ & 2.71 & 0.90 \\
\hline $\begin{array}{l}\text { Conducting online searching of information } \\
\text { on analgesics }\end{array}$ & $21(14.4)$ & $61(41.8)$ & $44(30.1)$ & $20(13.7)$ & 2.57 & 0.90 \\
\hline $\begin{array}{l}\text { Information Use: } \\
\text { I use information I obtain regarding pain } \\
\text { management to: }\end{array}$ & & & & & 3.45 & 0.47 \\
\hline Analyze patient's pain assessment data & $89(61.0)$ & $53(36.2)$ & $02(1.4)$ & $02(1.4)$ & 3.57 & 0.60 \\
\hline Document pain management care delivered & $74(50.7)$ & $65(44.5)$ & $07(4.8)$ & 0 & 3.46 & 0.59 \\
\hline Interpret patient's pain assessment data & $71(48.6)$ & $69(47.3)$ & $04(2.7)$ & $02(1.4)$ & 3.43 & 0.62 \\
\hline $\begin{array}{l}\text { Evaluate effectiveness of scheduled analgesics } \\
\text { administered }\end{array}$ & $68(46.6)$ & $72(49.3)$ & $05(3.4)$ & $01(0.7)$ & 3.42 & 0.60 \\
\hline Report on patient's condition & $73(50.0)$ & $62(42.5)$ & $10(6.8)$ & $01(0.7)$ & 3.42 & 0.65 \\
\hline Report on effect of pain treatment on patient & $62(42.5)$ & $78(53.4)$ & $06(4.1)$ & 0 & 3.38 & 0.57 \\
\hline Confirm analgesics medication dose & $76(52.1)$ & $56(38.3)$ & $07(4.8)$ & $07(4.8)$ & 3.38 & 0.79 \\
\hline $\begin{array}{l}\text { Analyze nurses' report on patient's experience } \\
\text { with pain relief }\end{array}$ & $61(41.8)$ & $74(50.7)$ & $10(6.8)$ & $01(0.7)$ & 3.34 & 0.64 \\
\hline $\begin{array}{l}\text { Confirm time of administration of scheduled } \\
\text { analgesics }\end{array}$ & $69(47.3)$ & $55(37.7)$ & $18(12.3)$ & $04(2.7)$ & 3.29 & 0.79 \\
\hline $\begin{array}{l}\text { Educate patients on their role in scheduled } \\
\text { analgesics administration }\end{array}$ & $45(30.8)$ & $82(56.2)$ & $17(11.6)$ & $02(1.4)$ & 3.16 & 0.68 \\
\hline $\begin{array}{l}\text { Educate patients on their role in the overall } \\
\text { pain management }\end{array}$ & $46(31.7)$ & $74(50.8)$ & $22(15.4)$ & $03(2.1)$ & 3.12 & 0.73 \\
\hline Discuss analgesic administration with patient & $45(30.8)$ & $72(49.4)$ & $24(16.4)$ & $05(3.4)$ & 3.08 & 0.78 \\
\hline Delegate role to colleagues / subordinates & $33(22.6)$ & $66(45.2)$ & $43(29.5)$ & $04(2.7)$ & 2.88 & 0.79 \\
\hline Average Weighted Mean & & & & & 3.46 & 0.39 \\
\hline
\end{tabular}

KEY: SA = Strongly Agree (4); A = Agree (3); D = disagree (2); SD = Strongly Disagree (1)

Decision Rule: If mean is 3.25 to $4.0=$ Very Good; 2.50 to $3.24=$ Good; 1.75 to $2.49=$ Fair; 1.0 to $1.74=$ Poor. Criterion Mean $=2.5$

Table 4 revealed that information behaviour of surgical nurses was very good. According to the result, the average weighted mean (3.46) is above the criterion mean of 2.5. Most of the surgical nurses strongly agreed that they sought and used information during pain management for post-operative patients. The result also showed that respondents' information seeking behaviour (average mean $=3.47$ ) and information use (average mean $=$ 3.45) regarding pain management were very good.

\section{Tests of Hypotheses}

The null hypothesis one was tested using single linear regression while hypothesis two was tested with multiple linear regressions. The results are presented in Table $5-6$.

Table 5: Influence of nurses' information behaviour on surgical patients' pain relief

\begin{tabular}{|l|l|l|l|l|c|}
\hline & B & Std. Error & Beta $(\boldsymbol{\beta})$ & T & Sig. \\
\hline (Constant) & 1.065 & .429 & & 2.480 & $.014^{*}$ \\
\hline Nurses information behaviour & .634 & .129 & .380 & 4.925 & $.000^{*}$ \\
\hline Dependent Variable: Surgical patients' pain relief
\end{tabular}

\section{$\mathrm{R}^{2}=.144 ; \mathrm{R}^{2}=.138$, Adjusted $; \mathrm{F}=24.253 ; \mathrm{DF}=1,144 ; \mathrm{P}<.05$}

Table 5 revealed that $14.4 \%\left(\mathrm{R}^{2}=0.144\right)$ of the change in the dependent variable (surgical patients' pain relief) is explained by the independent variable (nurses' information behaviour). The result indicates that nurses' information behaviour $(\beta=0.380, p<0.05)$ significantly influenced patients' pain relief in teaching hospitals in Port Harcourt $(F(1,144)=24.253, p<0.05)$. The $\mathrm{H}_{01}$ is therefore rejected. This result suggests that nurses' information behaviour improves level of surgical patients' pain relief in teaching hospitals in Port Harcourt. 
Table 6: Relative influence of the components of nurses' information behaviour on surgical patients' pain relief

\begin{tabular}{|l|l|l|l|l|l|}
\hline & \multicolumn{2}{|c|}{ Beta $(\boldsymbol{\beta})$} & T & Sig. & \multicolumn{2}{l|}{ Collinearity Statistics } \\
\cline { 3 - 6 } & & & & Tolerance & VIF \\
\hline (Constant) & & 2.211 & $.029 *$ & & \\
\hline Nurses Information seeking & .152 & 1.894 & $.050^{*}$ & .909 & 1.100 \\
\hline Nurses Information use & .323 & 4.014 & $.000 *$ & .909 & 1.100 \\
\hline
\end{tabular}

$\mathrm{R}^{2}=.157 ; \mathrm{R}^{2}=.146$, Adjusted $; \mathrm{F}=13.362 ; \mathrm{DF}=2,143 ; \mathrm{P}<.05$

Table 6 showed that nurses' information behaviour components namely, nurses' information seeking and nurses' information use jointly accounted for $14.6 \%\left(A d j . \mathrm{R}^{2}=0.146\right)$ of the changes in the surgical patients' pain relief. The result revealed that nurses' information seeking $(\beta=0.152, p<0.05)$ and nurses' information use $(\beta=$ $0.323, p<0.05)$ had significant positive influences on surgical patients' pain relief $(F(2,143)=13.362, p<$ 0.05). Therefore, null hypothesis two $\left(\mathrm{Ho}_{2}\right)$ was rejected. That the components of nurses' information behaviour had significant relative influence on surgical patients' pain relief in teaching hospitals in Port Harcourt, Nigeria. The result showed that nurses' information use contributes the more to surgical patients' pain relief than nurses' information seeking.

\subsection{Discussion of Findings}

Research question one examined the level of pain relief of surgical patients in teaching hospitals in Port Harcourt. The findings showed that surgical patients' level of pain relief was very high. This result is similar to the findings by the study conducted by Schroeder and colleagues (2016). Schroeder and colleagues studied the knowledge of pain assessment using single group quasi-experimental method. The study adopted pre-test and post-test method to analyse the knowledge of nurses in pain assessment. Their findings showed that nurses gained knowledge and that improved patients satisfaction with pain management. This satisfaction may have been possible because patients' pain relief improved.

Research question two examined surgical nurses' information behaviour regarding pain management in teaching hospitals in Port Harcourt. The result clearly showed that information behaviour of the nurses regarding pain management was good in teaching hospitals in Port Harcourt. The result of this study supports the study by Shakya and Shakya (2016) in Greece which concluded that, nurses with relevant information relating to pain management would make substantial advancement in patient's pain management care delivery.

Another major finding in the current study is that the information seeking behaviour of surgical nurses in teaching hospitals in Port Harcourt was very good. This finding agrees with earlier studies by Argyri et al. (2014) in Greece and that by Baro and Ebhomeya (2013) in Nigeria. The study by Argyri et al. (2014) concluded that nurses generally seek information related to their role and comprise information for nursing intervention which includes pain management and administration of analgesics. While, Baro and Ebhomeya (2013) found that nurses seek information for better patient care, improve medication administration, and enhance job performance. Therefore, it could be inferred that if nurses seek for information relating to analgesia, they would acquire it for appropriate decision making that would influence surgical patients' pain relief.

Another major finding in this study is the high level of information use of surgical nurses in teaching hospitals in Port Harcourt for patients' pain management. The finding of this study aligns with the study by Mubita and colleagues (2019) that investigated patient satisfaction with pain relief and found that patients achieve satisfaction when nurses communicated with patients which is an information use provide them appropriate pain management care. This study also agrees with the study by Glowacki (2015) who reported positive relationship between nurses' information use and pain management.

On the contrary, this study disagrees with the study by Zeb, Jewewria, Uzma and Bi-Bi (2019) which found that nurses have good knowledge of pain management but the effect of its use is not visible as patients pain were still undertreated. It could be possible that the nurses in the study by Zeb and colleagues (2019) did not use the information they acquired. This finding also disagrees with earlier studies by Chou and Colleagues (2016) in Asia and Onianwa et al. (2017) in Nigeria that showed that some nurses do not have the competency required in pain management practice. For instance, Chou and Colleagues (2016) suggest that nurses need to acquire relevant information pertaining to pain management for optimum care delivery, while Onianwa et al. (2017) found that nurses were deficient in their baseline pain management knowledge.

\subsection{Conclusion}

Pain relief is essential part of recovery after surgery in order to keep patients comfortable, to improve functional status and prevent post-operative complications. Pain relief can also improve other areas of health such as sleeping, positive emotional wellbeing, improved appetite and quick recovery from surgery. This study shows 
that nurses' information seeking and use positively influenced pain relief experience of surgical patients in teaching hospitals in Port Harcourt. Consequently, it is important for the management of teaching hospitals in Port Harcourt to give attention to seeking and using relevant information during post-operative pain management. This would enhance the information behaviour capacity of nurses in order to sustain the surgical patients' pain relief.

\subsection{Recommendations}

Based on the findings, the following recommendations are hereby proffered:

1. The administration of the teaching hospitals in Port Harcourt should mandate surgical nurses to focus on improving online searching for information on analgesics as well as listening to patients' family on concerns about patients' pain to enable them maintain above average performance in the information behaviour scale.

2. The directors of nursing in each surgical specialty in the teaching hospitals should ensure that nurses are mandated to reassess patients after administration of scheduled analgesics to obtain information to confirm effect of analgesics and ascertain pain relief.

3. The hospital administration in teaching hospitals in Port Harcourt should develop policies to encourage nurses' information use since it contributes the most influence on surgical patients' pain relief.

\subsection{Suggestions for further studies}

1. This study could be replicated in other cities in Nigeria to establish the information behaviour of surgical nurses with respect to pain management in such cities.

2. Other studies could be conducted on the information behaviour of nurses in the administration of other types of medication for treatment of diverse diseases and health complications.

\section{References}

Argyri, P., Kostagiolas, P., \& Diomidous, M. (2014). A survey on information seeking behaviour of nurses at a private hospital in Greece. Studies in Health Technology and Informatics, 7, 127-131.

Baro, E \& Ebhomeya, L. (2013). Information needs and seeking behaviour of nurses: A survey of two hospitals in Bayelsa State, Nigeria. Health Education, 113(3), 183-195.

Chou, R., Gordon, D. B., Leon-Casasola, O. A., Rosenberg, J. M., Bickler, S., Brennan, T., et al., (2016). Guidelines on the management of postoperative pain: A clinical practice guideline from the American Pain Society, the American Society of Regional Anesthesia \& Pain Medicine, and the American Society of Anesthesiologists' Committee on Regional Anesthesia, Executive Committee, and Administrative Council. The Journal of Pain, 17(2), 131-157.

Cronbach, L. (1951). Coefficient alpha and the internal structure of tests. Psychometrika, 16, 297-334.

Fishman, S. M., Young, H. M., Arwood, E. L., Chou, R., Herr, K., Murinson, B. B., et al., (2013). Core competencies for pain management: Results of an interprofessional Consensus Summit. The American Academy of Pain Medicine, 14, 971-981.

Glowacki, D. (2015). Effective Pain Management and Improvements in Patients' Outcomes and Satisfaction. Critical Care Nurse, 35(3), 33-41.

Hinkle, J. L. \& Cheever, K. H. (2018). Brunner \& Suddarth's Textbook of Medical - Surgical Nursing (14 ${ }^{\text {th }}$ Ed). Philadelphia, PA: Wolters Kluwer/Lippincott Williams \& Wilkins.

Kehinde, A. A., Obi, S. A., Akinade, A. A. \& Anyim, A. O. (2016). Information needs and seeking behaviour of Masters Students in faculty of communication and information sciences, University of Ilorin, Kwara State. Library Philosphy \& Practice (e.journal) 1463. Retrieved from http://digitalcommons.vol.edulibphilprad1463.

Krejcie, R. V. \& Morgan, D. W. (1970). Determining sample size for research activities. Educational and Psychological Measurement, 30, 607- 610.March, M. A., Vaikosen, H. A. \& Akporoghene, E. A. (2020). Information needs and seeking behaviour of nurses at Rivers State University Teaching Hospital (RSUTH), Port Harcourt. Journal of Information and Knowledge Management, 11(3), 63-74.

Mubita, W. M., Richardson, C. \& Briggs, M. (2019). Patient satisfaction with pain relief following major abdominal surgery is influenced by good communication, pain relief and empathic caring: a qualitative interview study. British Journal of Pain, 14(1), 14-22.

Nwagwu, W. E., \& Oshiname, R. (2009). Information needs and seeking behaviour of nurses at the University College Hospital, Ibadan, Nigeria. Afr J Libr Arch Inf Sci19(1), 25-38.

Onianwa, P. O., Alonge, T. O., Otegbayo, J. A., Ike, E. U., Chukura, O. O., Akanbi, F. O. M., et al. (2017). Pain as 5th vital sign: impact of pain assessment training program on Nigerian nurses' knowledge of pain management. International Journal of Midwifery, 9 (11), 129-135. Doi: 10.5897/IJNM2017.0283

Opeke, R. O. (2017). Information, Life... And Eternity. $18^{\text {th }}$ Babcock University Inaugural Lecture. Department 
of Information Resources Management. Ilishan-Remo, Ogun State: Babcock University Press.

Rababa, M. (2018). The role of Nurses' uncertainty in decision-making process of pain management in people with dementia. Pain Research and Treatment, 2018, 1-7. https//doi.org/10.1155/2018/7281657

Sampson, M. (2013). Seeking consistency when managing patients' pain. Kai Tiaki Nursing New Zealand, $19(5), 26-28$.

Schroeder, D. L., Hoffman, L. A., Fioravanti, M., Medley, D. P., Zullo, T. G., \& Tuite, P. K. (2016). Enhancing nurses' pain assessment to improve patient satisfaction. Orthorpaedic Nursing, 35(2), 108-117.

Shakya, S. \& Shakya, B. (2016). Knowledge and Attitude of nurses on pain management in a Tertiary Hospital in Nepal. International Journal of Nursing Research and Practice, 3(1), $3-8$.

Stodart, K, \& McCallum, K. (2014). Take away the pain. Kai Tiaki Nursing New Zealand, 20(6), 14-16.

Subramanian, B., Shastri, N., Aziz, L., Gopinath, R., Karlekar, A., Mehta, Y. . . . Jain, P. (2017). ASSISTPatient satisfaction survey in postoperative pain management from Indian Subcontinent. Journal of Anaesthesiology Clinical Pharmacology, 30, 40-47. DOI: 10.4103/joacp.JAOCP 24516

Vigharajah, Hassan, F. A., Abd Aziz, N. \& Lee, O. S. (2016). Profiling information seeking behaviour of distance learning students in Wawasan Open University . Asian Association of Open University Journal, 11(2), 122-135.

Zeb, A., Farhana, Jewewria, Marym, Uzma, \& Nadra Bi Bi. (2019). Nurses' knowledge regarding post-operative pain management. Journal of Healthcare Communication, 4(1), 1-4. 